\title{
NUTRITIONAL STATUS OF THE FREE-LIVING ELDERLY
}

\author{
İsmail Özkaya
}

Department of Nutrition and Dietetics, School of Health, Kırklareli University, Kırklareli, Turkey

\begin{abstract}
SUMMARY
Objectives: Measuring malnutrition is difficult in all settings and confused with the signs of aging. Mini nutritional assessment is an effective tool designed to identify older adults who have a risk of developing malnutrition.

Methods: Three hundred and one free-living elderly who lived with their family or alone were included in the study. Nutritional screening was performed with mini nutritional assessment and mini nutritional assessment short form. Dietary intake was assessed by a 3-days weighted food record.

Results: According to mini nutritional assessment in the 65-74 years young-old group, malnutrition, risk of malnutrition, and normal nutrition was $2.4 \%, 39.5 \%, 58.2 \%$, respectively, and in the $75-84$ years old-old group it was $10.2 \%, 48.7 \%, 41.0 \%$, respectively, and in the older than 85 years oldest-old group $92.3 \%, 7.7 \%, 0 \%$, respectively. The lowest nutritional intake by recommended dietary allowance was zinc and the highest intake was sodium. Neither young-old group nor old-old group nor oldest-old group met the B12 and zinc requirements.

Conclusions: The free-living elderly at an age of 85 years and above are, accompanied by the existence of factors which may mask their weight losses, under a severe risk of malnutrition unless they receive adequate medical care and attention.
\end{abstract}

Key words: elderly, nutritional status, nutritional assessment, nutritional intakes, MNA, malnutrition

Address for correspondence: I. Özkaya, Kırklareli University, School of Health, Department of Nutrition and Dietetics, Kırklareli, Turkey. E-mail: dytismail@hotmail.com

https://doi.org/10.21101/cejph.a5925

\section{INTRODUCTION}

Malnutrition is not understood as a "little nutrition" instead of "bad nutrition". Malnutrition is a syndrome characterized by inadequate intake and absorption of nutrients (1).

In the aging process many variables, including marital status, cognitive status, activities of daily living and independent activities of daily living limitations, social engagement, metabolic changes, and decreased appetite are associated with increased depression and malnutrition $(2,3)$.

The changes to the sense of smell, taste and even hearing which increase with the ageing process can affect the enjoyment of food and this can lead to inadequate nutritional intake and malnutrition $(4,5)$.

Malnutrition is associated with an increased length of hospital stay, reduction in quality of life, delayed wound healing, increase of adverse health conditions such as infection and functional capacity. Malnutrition is especially determinative for morbidity and mortality in the elderly (6).

The prevalence of malnutrition is relatively low in the freeliving elderly $(2-10 \%)$, but rises considerably $(30-60 \%)$ in the hospitalized or institutionalized elderly (7).

Measuring malnutrition is difficult in all settings and confused with the signs of aging (8).

The mini nutritional assessment (MNA) is an effective tool designed to identify older adults who have a risk of developing malnutrition (9). The MNA has a short form (MNA-SF). The MNA and MNA-SF are sensitive, specific and accurate in identifying nutrition risk (10).
MNA and MNA-SF are applicable to screen malnutrition in Turkish geriatric patients (11).

In this study, we aimed at identifying, by means of the MNA and MNA-SF, malnutrition, malnutrition risks and inadequate food intake ratios in the free-living elderly groups.

\section{MATERIALS AND METHODS}

\section{Setting and Sampling}

In this study, between January 2017 and December 2018, 1,000 elderly persons were called by phone through the neighbourhood mukhtar's offices and were asked whether they would like to participate in the study; 388 elderly persons who agreed to participate in the study were met face to face. The exclusion criteria were receiving supplements $(n=8)$ or tube feeding $(n=2)$, suffering from acute disease at the beginning of the study $(n=28)$, being in a terminal condition of health $(n=13)$, suffering from cognitive impairment $(n=16)$. Upon further exclusion of the elderly, whose detailed food consumption could not be obtained $(n=20), 301$ free-living elderly who lived with their family or alone in their own houses were included in the study. They were older than 65 years. They were living in Kirklareli city centre or districts of Kirklareli or villages of this districts (50 villages of 8 districts), and they were never institutionalized or living in nursing home.

The socio-demographic data of the elderly were collected using face-to-face questionnaire. The study population was divided into 3 subgroups, whereby the group comprising age between 65-74 
years is young-old, 75-84 years of age is old-old, and over 85 years of age is oldest-old (12).

\section{Nutritional Status of the Elderly}

Nutritional screening was performed with MNA-SF and MNA. The MNA was validated against two principal criteria, the clinical status and comprehensive nutrition assessment, by applying principal component and discriminant analysis. The MNA-SF was developed and validated to allow a 2 -step screening process. MNA-SF, which is the first step, consists of six items: food intake, weight loss, mobility, psychological stress or acute disease, neuropsychological problems, and body mass index (BMI). The maximum score of MNA-SF is 14. A score equal to or less than 7 points is regarded as an indicator of malnutrition, $8-11$ points indicate a risk for malnutrition, and a score equal to or more than 12-14 points indicate that the person is well nourished. If indicated ( $<12$ point) after step 1 (MNA-SF), the risk of malnutrition should be assessed using the full MNA. Accordingly, for the purpose of the present malnutrition study, we have assessed those persons, who have scored less than 12 in the MNA-SF, in the scope of the full MNA. In the full MNA, a total score of less than 17 points is regarded as an indicator of malnutrition, 17-23.5 points indicate a risk of malnutrition, and more than 23.5 points indicate that the person is well nourished (Fig. 1). The sum of malnutrition and risk of malnutrition considered the risk of poor nutritional status $(13,14)$.

The weight has been measured by means of a portable bascule, and the height by means of a portable stadiometer. The bascule used featured a measurement precision of $100 \mathrm{~g}$ intervals, and the stadiometer with $1 \mathrm{~mm}$ intervals. The height has been measured while the patient was in his/her room clothes and shoes off, his/her back resting at the stadiometer. The patient's heels have been kept parallel and adjacent to each other. During the height measurement, attention has been paid to orbitomeatal line (Frankfurt plan), i.e., the plane combining the ear meatus and the bottom of the orbital cavity, was parallel to the floor, and the heel, gluteus and occiput protrusion rested against the stadiometer. A slight pressure has been applied on the patient's processus mastoideus, it has been

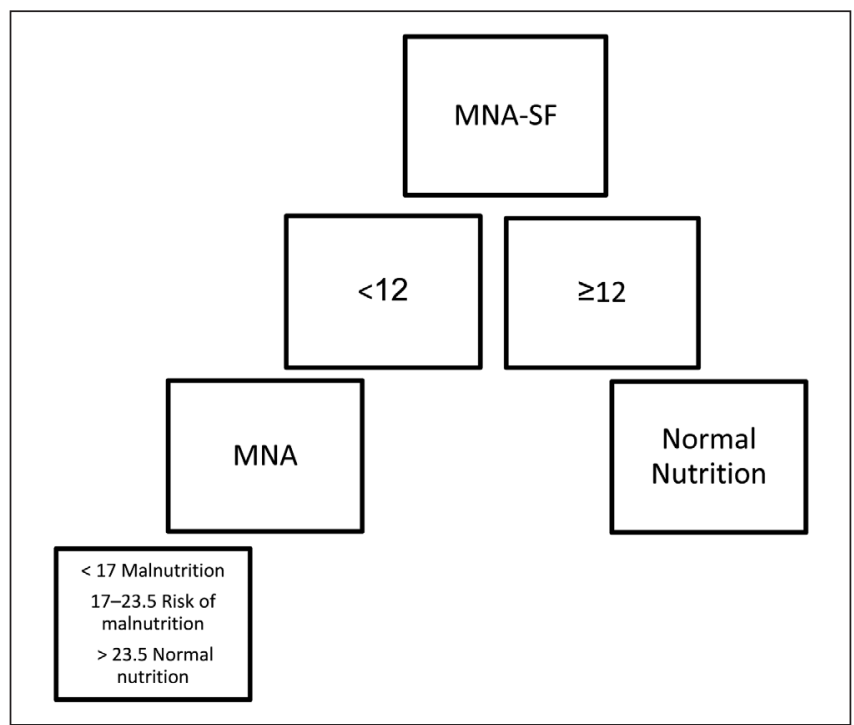

Fig. 1. Assessment of malnutrition by MNA. pulled upward, and thus the patient has been ensured to stand fully upright. The waist circumference (WC) has been measured as the narrowest body diameter between the crista iliaca and the arcus costarum, and the hip circumference (HC) has been measured as the broadest body diameter over the gluteus maximus behind and over the pubis in front. The mid-upper arm circumference (MUAC) measured at the mid-point between the tip of the shoulder and the tip of the elbow (olecranon process and the acromion).

All anthropometric measurements were made on two different days and the mean of all these values was calculated. Thus, the occurrence of faults depending on intraobserver variability were prevented.

\section{Energy and Nutrients Intake of the Elderly}

Dietary intake was assessed by a 3-day weighed food record. The participants were asked to record everything they ate and drank for three consecutive days which included two weekdays and one weekend day (Thursday, Friday and Saturday; or Sunday, Monday and Tuesday). They were instructed not to alter what they ate or drank during this time. The amount of food and beverages was determined by using "household measures" and "ml" or "grams" based on the Turkish Ministry of Health - General Directorate of Primary Health Care, Portion Sizes for Age Groups Guideline (15). Also, a photographic atlas was used to determine the food portion sizes (16). To estimate the amounts of food in one portion consumed outside the institutions, standard dishes description was used (17). In addition, details of any vitamin and mineral supplements consumed in the 3-day period were recorded. Mean energy, macronutrient and food intakes of the elderly by age groups were calculated using BEBIS 7 software, which was also double entered to ensure verification (Ebispro for Windows, Germany; Turkish version/BeBiS 7). Results were compared with Turkish recommended daily allowances (RDA) according to age and gender (15). Nutrient intake below two-thirds of RDA (67\%) was considered low intake (18). Calculations of energy, nutrients intake and level of meeting daily requirements are based on the risk of poor nutritional status of the elderly.

\section{Statistical Methods}

Data were analysed with SPSS version 20.0 (Chicago, IL, USA) using number (n), percentage (\%), mean (X), standard deviation (SD), and median values. Normal distribution of data was checked by means of the Shapiro-Wilk test. Groups were compared by means of the one-way analysis of variance (ANOVA) for normal distributed, or by the Kruskal-Wallis test for not normally distributed variables. Tukey HSD analysis was performed for multiple comparisons of groups after ANOVA and pairwise comparisons were performed after Kruskal-Wallis test. Chi-square test $\left(\chi^{2}\right)$ was used in comparison of qualitative variables between groups. Fisher's exact test result was excepted when expected numbers were small. P-value $<0.05$ was set as statistically significant.

\section{Ethical Approval}

All participants of this study gave their written informed consent and ethical approval was obtained from the Kırklareli University Ethical Review Committee. 


\section{RESULTS}

\section{Socio-demographic Characteristics}

The socio-demographic characteristics of the study participants are shown in Table 1. There were 157 (52.2\%) males and $144(48.8 \%)$ females. The proportion of young-old, old-old and oldest-old males was $82.8 \%, 12,7 \%$ and $4.5 \%$, respectively. The proportion of young-old, old-old and oldest-old females was $82.6 \%, 13.2 \%$ and $4.2 \%$, respectively. There is no statistical difference in gender distribution among older groups ( $p>0.05)$.

Only $4.5 \%$ of the elderly males were illiterate, $41.4 \%$ were literate without formal education, and $54.1 \%$ had formal education;
$15.2 \%$ of the elderly females were illiterate, $41.7 \%$ were literate without formal education, and $43.1 \%$ had formal education.

$83.4 \%$ of the elderly males were married, $14.6 \%$ were widowed and $1.9 \%$ were divorced. On the other hand, $83.3 \%$ of the elderly females were married, $14.6 \%$ were widowed, and $2.1 \%$ were divorced.

$9.6 \%$ of the elderly males were living alone and $89.8 \%$ were living with their family. Similarly, $9.7 \%$ of the elderly females were living alone and $91 \%$ were living with their family.

Among the elderly males $44.6 \%$ had quit smoking, 25.5\% were smokers, and $29.9 \%$ never smoked; among the elderly females $44.4 \%$ quit smoking, $4.1 \%$ were smokers, and $51.3 \%$ never smoked.

Table 1. Socio-demographic characteristics of the elderly $(N=301)$

\begin{tabular}{|c|c|c|c|c|c|}
\hline & & \multicolumn{2}{|c|}{ Males $(n=157)$} & \multicolumn{2}{|c|}{ Females $(n=144)$} \\
\hline & & $\mathrm{n}$ & $\%$ & $\mathrm{n}$ & $\%$ \\
\hline \multirow{3}{*}{ Age groups (years) } & Young-old 65-74 & 130 & 82.8 & 119 & 82.6 \\
\hline & Old-old 75-84 & 20 & 12.7 & 19 & 13.2 \\
\hline & Oldest-old 85+ & 7 & 4.5 & 6 & 4.2 \\
\hline \multirow{6}{*}{ Education status } & Illiterate & 7 & 4.5 & 22 & 15.2 \\
\hline & Literate (without formal education) & 65 & 41.4 & 60 & 41.7 \\
\hline & Primary school & 54 & 34.4 & 49 & 34.0 \\
\hline & Secondary school & 12 & 7.6 & 7 & 4.8 \\
\hline & High school & 16 & 10.2 & 5 & 3.4 \\
\hline & University & 3 & 1.9 & 2 & 1.4 \\
\hline \multirow{3}{*}{ Marital status } & Married & 131 & 83.4 & 120 & 83.3 \\
\hline & Widowed & 23 & 14.6 & 21 & 14.6 \\
\hline & Divorced & 3 & 1.9 & 3 & 2.1 \\
\hline \multirow{2}{*}{ Living status } & Alone & 15 & 9.6 & 14 & 9.7 \\
\hline & With family & 141 & 89.8 & 131 & 91.0 \\
\hline \multirow{3}{*}{ Smoking status } & Smoker & 40 & 25.5 & 6 & 4.1 \\
\hline & Quit & 70 & 44.6 & 64 & 44.4 \\
\hline & Never & 47 & 29.9 & 74 & 51.3 \\
\hline \multirow{5}{*}{ Previous occupation } & Worker & 43 & 27.4 & 19 & 13.1 \\
\hline & Housewife & 0 & 0.0 & 86 & 59.7 \\
\hline & Farmer & 42 & 26.8 & 32 & 22.2 \\
\hline & Officer & 35 & 22.3 & 6 & 4.1 \\
\hline & Tradesman & 37 & 23.6 & 1 & 0.6 \\
\hline \multirow{10}{*}{ Diagnosed diseases } & Hypertension & 96 & 61.1 & 88 & 61.1 \\
\hline & Cardiovascular & 51 & 32.5 & 47 & 32.6 \\
\hline & Rheumatic & 36 & 0.9 & 34 & 23.6 \\
\hline & Diabetes mellitus & 107 & 68.1 & 103 & 71.5 \\
\hline & Respiratory diseases & 17 & 10.8 & 13 & 9.0 \\
\hline & Gastrointestinal & 38 & 24.2 & 36 & 25.0 \\
\hline & Osteoporosis & 97 & 61.8 & 1 & 84.7 \\
\hline & Nervous & 18 & 11.5 & 17 & 11.8 \\
\hline & Kidney & 14 & 8.9 & 13 & 9.0 \\
\hline & Others ${ }^{a}$ & 27 & 17.2 & 25 & 17.4 \\
\hline
\end{tabular}

aProblems of eye $(n=26)$; hearing $(n=3)$; oral-dental $(n=8)$; skin $(n=3)$; prostate $(n=19)$; goiter $(n=9)$; liver disease $(n=2)$; allergy $(n=1)$ 
As regards their previous occupations, $27.4 \%$ of males and $13.1 \%$ of females were workers, $26.8 \%$ of males and $22.2 \%$ of females were farmers, $22.3 \%$ of males and $4.1 \%$ of females were officers, $23.6 \%$ of males and $0.6 \%$ of females were tradesmen, and $59.7 \%$ of females were housewives.

In both genders their most prevalent health problems were diabetes mellitus (70\%), osteoporosis $(70 \%)$, and hypertension, (61\%).

\section{Nutritional Status}

The anthropometric measurements of the participants by gender are presented in Table 2. The mean age was $70.0 \pm 4.9$ (65-87) years for males and 70.4 $\pm 5.2(65-88)$ years for females (ns). Mean BMI was $28.7 \pm 5.3 \mathrm{~kg} / \mathrm{m}^{2}$ for males and $30.0 \pm 3.4$ $\mathrm{kg} / \mathrm{m}^{2}$ for females (ns). Mean WC was $118.0 \pm 9.6 \mathrm{~cm}$ for males and $125.0 \pm 11.5 \mathrm{~cm}$ for females $(\mathrm{p}<0.001)$. Mean HC was $107.6 \pm 6.8 \mathrm{~cm}$ for males and $113.0 \pm 11.2 \mathrm{~cm}$ for females $(\mathrm{p}<0.001)$. Mean $\mathrm{W} / \mathrm{H}$ ratio was $1.01 \pm 0.08$ for males and $1.11 \pm 0.12$ for females $(p<0.001)$. Mean MUAC was $29.2 \pm 5.7$ $\mathrm{cm}$ for males and $28.8 \pm 4.6 \mathrm{~cm}$ for females (ns).

The nutritional status of the free-living elderly is shown in Table 3. The BMI of young-old, old-old and oldest-old elderly was $29.3 \pm 4.9 \mathrm{~kg} / \mathrm{m}^{2}, 28.0 \pm 3.7 \mathrm{~kg} / \mathrm{m}^{2}$, and $33.2 \pm 4.8 \mathrm{~kg} / \mathrm{m}^{2}$, respectively. The waist circumference of young-old, old-old and oldest-old elderly was $108.8 \pm 11.2 \mathrm{~cm}, 118.6 \pm 17 \mathrm{~cm}$, and $126.6 \pm 15.0 \mathrm{~cm}$, respectively. $\mathrm{W} / \mathrm{H}$ ratio was $0.95 \pm 0.11$ in young-old, $1.01 \pm 0.17$ in old-old, and $0.94 \pm 0.03$ in oldest-old elderly. The MUAC of young-old, old-old and oldest-old elderly was $28.91 \pm 5.39 \mathrm{~cm}, 30.86 \pm 3.91 \mathrm{~cm}$, and $21.24 \pm 1.38 \mathrm{~cm}$, respectively.

According to the MNA-SF in the young-old group, malnutrition, risk of malnutrition, risk of poor nutritional status, and normal status was $3.6 \%, 41.7 \%, 45.3 \%, 54.7 \%$, respectively, in the old-old group it was $12.8 \%, 56.4 \%, 69.3 \%, 30.7 \%$, respectively, and in the oldest-old group $92.3 \%, 7.7 \%, 100 \%$, $0 \%$, respectively. According to full MNA in the young-old group, malnutrition, risk of malnutrition, risk of poor nutritional status, and normal nutrition was $2.4 \%, 39.5 \%, 41.8 \%, 58.2 \%$, respectively, in the old-old group it was $10.2 \%, 48.7 \%, 59.0 \%$, $41.0 \%$, respectively, and in the oldest-old group $92.3 \%, 7.7 \%$, $100 \%, 0 \%$, respectively. Young-old versus old-old, young-old versus oldest-old, and old-old versus oldest-old groups were significantly different for MNA and MNA-SF $(p<0.001)$. As the result of the full MNA, 140 elderly people have the risk of poor nutritional status (Table 4).

\section{Energy and Nutrients Intake}

As shown in Table 5, 140 elderly people have the risk of poor nutritional status in the young-old group, energy, carbohydrate, protein, and fat intake were found to be $1,672.5 \pm 553.2 \mathrm{kcal} / \mathrm{d}$, $217.2 \pm 100.9 \mathrm{~g} / \mathrm{d}, 61.2 \pm 24.1 \mathrm{~g} / \mathrm{d}$, and $60.8 \pm 26.0 \mathrm{~g} / \mathrm{d}$, respectively. In the old-old group, energy, carbohydrate, protein, and fat

Table 2. Anthropometric measurements of participants by gender $(N=301)$

\begin{tabular}{|c|c|c|c|c|c|}
\hline & \multicolumn{2}{|c|}{ Males $(n=157)$} & \multicolumn{2}{|c|}{ Females $(n=144)$} & \multirow{2}{*}{ p-value } \\
\hline & Mean (SD) & Range & Mean (SD) & Range & \\
\hline Age & $70.0(4.9)$ & $65-87$ & $70.4(5.2)$ & $65-88$ & ns \\
\hline Height (cm) & $168.3(8.1)$ & $150-190$ & $156.5(7.2)$ & $140-170$ & $<0.001$ \\
\hline Weight (kg) & $80.7(9.8)$ & $65-120$ & $70.1(11.8)$ & $63-110$ & $<0.001$ \\
\hline $\mathrm{BMI}\left(\mathrm{kg} / \mathrm{m}^{2}\right)$ & $28.7(5.3)$ & $25-40.3$ & $30.0(3.4)$ & $25-49$ & ns \\
\hline Waist circumference (cm) & $118.0(9.6)$ & $90-168$ & $125.0(11.5)$ & $72-143$ & $<0.001$ \\
\hline Hip circumference $(\mathrm{cm})$ & $107.6(6.8)$ & $90-123$ & $113.0(11.2)$ & $61-135$ & $<0.001$ \\
\hline Waist to hip ratio & $1.01(0.08)$ & $0.9-1.6$ & $1.11(0.12)$ & $0.7-1.8$ & ns \\
\hline Mid-upper arm circumference (cm) & $29.2(5.7)$ & $20.2-44.4$ & $28.8(4.6)$ & $18.3-38.8$ & ns \\
\hline
\end{tabular}

The significance of the variables was tested using the independent $t$ test.

$\mathrm{SD}$ - standard deviation; ns - not significant

Table 3. Nutritional status of the free-living elderly $(N=301)$

\begin{tabular}{|c|c|c|c|c|}
\hline & $\begin{array}{c}\text { Young-old }(n=249) \\
\text { Mean (SD) }\end{array}$ & $\begin{array}{c}\text { Old-old }(n=39) \\
\text { Mean (SD) }\end{array}$ & $\begin{array}{l}\text { Oldest-old }(n=13) \\
\text { Mean (SD) }\end{array}$ & $\begin{array}{c}\text { Total } \\
\text { Mean (SD) }\end{array}$ \\
\hline Height $(\mathrm{cm})$ & $163.7(10.3)^{A, B}$ & $159.5(10.5)^{\mathrm{A}}$ & $158.3(2.9)^{\mathrm{B}}$ & $163.1(10.3)$ \\
\hline Weight (kg) & $78.3(13.5)^{A}$ & $71.0(9.0)^{A, C}$ & $83.3(7.6)^{\mathrm{C}}$ & $77.4(13.2)$ \\
\hline $\mathrm{BMI}\left(\mathrm{kg} / \mathrm{m}^{2}\right)$ & $29.3(4.9)^{\mathrm{BB}}$ & $28(3.7)^{\mathrm{C}}$ & $33.2(2.0)^{\mathrm{C}}$ & $29.2(4.8)$ \\
\hline Waist circumference $(\mathrm{cm})$ & $108.8(11.2)^{\mathrm{AA}}$ & $118.0(17.0)^{A A, C C}$ & $126.6(15.0)^{c c}$ & $115.5(14.2)$ \\
\hline Hip circumference $(\mathrm{cm})$ & $108.3(10.2)^{\mathrm{AA}, \mathrm{B}}$ & $102.3(11.1)^{A A, C}$ & $118.7(10.0)^{\mathrm{B}, \mathrm{C}}$ & $107.6(10.6)$ \\
\hline Waist to hip ratio & $0.99(0.11)$ & $1.08(0.17)$ & $1.10(0.03)$ & $1.04(0.12)$ \\
\hline Mid-upper arm circumference $(\mathrm{cm})$ & $28.91(5.39)^{\mathrm{B}}$ & $30.86(3.91)^{\mathrm{C}}$ & $21.24(1.38)^{\mathrm{B}, \mathrm{C}}$ & $28.58(5.34)$ \\
\hline
\end{tabular}

SD - standard deviation; young-old vs. old-old: ${ }^{A} p<0.001$, ${ }^{A A} p<0.05$; young-old vs. oldest-old: ${ }^{B} p<0.001,{ }^{B B} p<0.05$; old-old vs. oldest-old: ${ }^{C} p<0.001,{ }^{C C} p<0.05$ 
Table 4. MNA-SF and full MNA distributions of elderly groups $(N=301)$

\begin{tabular}{|c|c|c|c|c|c|}
\hline & & $\begin{array}{c}\text { Young-old ( } n=249) \\
n(\%)\end{array}$ & $\begin{array}{c}\text { Old-old }(n=39) \\
n(\%)\end{array}$ & $\begin{array}{c}\text { Oldest-old }(n=13) \\
n(\%)\end{array}$ & Total \\
\hline \multirow{4}{*}{ MNA-SF } & Malnutrition & $9(3.6)^{A, B}$ & $5(12.8)^{\mathrm{A}, \mathrm{C}}$ & $12(92.3)^{B, C}$ & $26(8.6)$ \\
\hline & Risk of malnutrition & $104(41.7)^{\mathrm{A}, \mathrm{B}}$ & $22(56.4)^{A, C}$ & $1(7.7)^{\mathrm{B}, \mathrm{C}}$ & $127(42.2)$ \\
\hline & Risk of poor nutritional status & $113(45.3)^{A, B}$ & $27(69.3)^{A, C}$ & $13(100)^{B, C}$ & $153(50.8)$ \\
\hline & Normal nutrition & $136(54.7)^{\mathrm{A}, \mathrm{B}}$ & $12(30.7)^{A, C}$ & $0(0)^{B, C}$ & $148(49.2)$ \\
\hline \multirow{4}{*}{ Full MNA } & Malnutrition & $6(2.4)^{A, B}$ & $4(10.2)^{A, C}$ & $12(92.3)^{B, C}$ & $22(7.3)$ \\
\hline & Risk of malnutrition & $98(39.5)^{A, B}$ & $19(48.7)^{A, C}$ & $1(7.7)^{\mathrm{B}, \mathrm{C}}$ & $118(39.2)$ \\
\hline & Risk of poor nutritional status & $104(41.8)^{\mathrm{A}, \mathrm{B}}$ & $23(59.0)^{A, C}$ & $13(100)^{B, C}$ & $140(46.5)$ \\
\hline & Normal nutrition & $145(58.2)^{A, B}$ & $16(41.0)^{A, C}$ & $0(0)^{B, C}$ & $161(53.5)$ \\
\hline
\end{tabular}

Young-old vs. old-old: ${ }^{A} p<0.001,{ }^{A A} p<0.05$; young-old vs. oldest-old: ${ }^{B} p<0.001,{ }^{B B} p<0.05$; old-old vs. oldest-old: ${ }^{C} p<0.001,{ }^{C C} p<0.05$

Table 5. Daily energy and nutrient intake of elderly groups $(N=140)$

\begin{tabular}{|c|c|c|c|c|}
\hline & $\begin{array}{c}\text { Young-old }(n=104) \\
\text { Mean (SD) }\end{array}$ & $\begin{array}{l}\text { Old-old }(n=23) \\
\text { Mean (SD) }\end{array}$ & $\begin{array}{c}\text { Oldest-old }(n=13) \\
\text { Mean (SD) }\end{array}$ & $\begin{array}{c}\text { Total } \\
\text { Mean (SD) }\end{array}$ \\
\hline Energy (kcal) & $1,672.5(553.2)^{A, B}$ & $1,361.7(379.1)^{\mathrm{A}, \mathrm{C}}$ & $1,111.8(198.7)^{\mathrm{B}, \mathrm{C}}$ & $1,589.2(23.0)$ \\
\hline Carbohydrate (g) & $217.2(100.9)^{A, B}$ & $186.3(66.7)^{\mathrm{A}, \mathrm{C}}$ & $119.5(27.9)^{\mathrm{B}, \mathrm{C}}$ & $203.5(66.9)$ \\
\hline Protein (g) & $61.2(24.1)^{A, B}$ & $54.9(16.5)^{A, C}$ & $41.5(11.0)^{\mathrm{B}, \mathrm{C}}$ & $55.6(21.0)$ \\
\hline Fat (g) & $66.8(26.0)^{A, B}$ & $52.8(19.4)^{A, C}$ & $52.8(19.4)^{A, C}$ & $56.9(17.1)$ \\
\hline Vitamin A (IU) & $1,626.7(1,071.4)^{A, B B}$ & $1,596.9(818.2)^{\mathrm{A}, \mathrm{CC}}$ & $1,343,7(801.0)^{\mathrm{BB}, \mathrm{CC}}$ & $1,514.0(921.0)$ \\
\hline Vitamin E (mg) & $22.6(10.70)^{\mathrm{BB}}$ & $21.36(10.56)^{c}$ & $17.16(5.96)^{\mathrm{BB}}$ & $20.7(8.45)$ \\
\hline Vitamin B1 (mg) & $1.0(0.20)^{A, B B}$ & $0.78(0.12)^{A}$ & $0.59(0.22)^{\mathrm{BB}}$ & $0.85(0.18)$ \\
\hline Vitamin B2 (mg) & $1.7(0.50)^{A A, B}$ & $1.28(0.30)^{\mathrm{AA}}$ & $1.18(0.22)^{\mathrm{B}}$ & $1.58(0.49)$ \\
\hline Vitamin B6 (mg) & $1.7(0.40)^{A A, B}$ & $1.32(0.32)^{\mathrm{AA}, \mathrm{C}}$ & $1.10(0.22)^{B, C}$ & $1.50(0.42)$ \\
\hline Vitamin B12 (mg) & $3.0(2.20)^{B B}$ & $3.82(3.05)^{c}$ & $2.46(1.41)^{B B}$ & $3.06(2.10)$ \\
\hline Folate $(\mu g)$ & $301.0(87.4)^{\mathrm{BB}}$ & $273.7(80.0)^{c c}$ & $229.5(33.4)^{\mathrm{BB}, \mathrm{CC}}$ & $279.9(85.7)$ \\
\hline Vitamin C (mg) & $155.6(66.6)^{\mathrm{BB}}$ & $133.6(50.0)^{c}$ & $103.5(32.8)^{\mathrm{BB}, \mathrm{C}}$ & $139.5(47.04)$ \\
\hline $\mathrm{Na}(\mathrm{mg})$ & $6,365.0(2,539.8)^{A, B}$ & $7,400.7(2,642.9)^{A, C}$ & $8,705.1(1,173.0)^{B, C}$ & $6,752.4(2,429.0)$ \\
\hline Calcium (mg) & $801.6(199.5)^{A, B}$ & $668.2(81.3)^{\mathrm{B}, \mathrm{C}}$ & $475.9(60.0)^{\mathrm{B}, \mathrm{C}}$ & $730.6(81.1)$ \\
\hline Magnesium (mg) & $244.0(71.5)^{\mathrm{BB}}$ & $233.4(71.2)^{c c}$ & $157.5(33.3)^{\mathrm{B}, \mathrm{C}}$ & $241.3(72.2)$ \\
\hline Iron (mg) & $11.44(4.04)^{\mathrm{BB}}$ & $10.82(4.76)^{c c}$ & $6.80(2.89)^{\mathrm{B}, \mathrm{C}}$ & $10.77(3.70)$ \\
\hline Copper (mg) & $1.9(1.30)^{A, B B}$ & $2.05(1.67)^{A, C C}$ & $2.68(1.75)^{\mathrm{BB}, \mathrm{CC}}$ & $1.99(1.60)$ \\
\hline Zinc (mg) & $6.96(3.22)^{\mathrm{AA}}$ & $5.70(2.48)^{\mathrm{AA}, \mathrm{CC}}$ & $4.74(1.41)^{C C}$ & $5.18(2.39)$ \\
\hline
\end{tabular}

Young-old vs. old-old: ${ }^{A} p<0.001,{ }^{A A} p<0.05$; young-old vs. oldest-old: ${ }^{B} p<0.001,{ }^{B B} p<0.05$; old-old vs. oldest-old: ${ }^{C} p<0.001,{ }^{C{ }^{C}} p<0.05$

intake were found to be $1,461.7 \pm 379,1 \mathrm{kcal} / \mathrm{d}, 186,3 \pm 66.7 \mathrm{~g} / \mathrm{d}$, $54.9 \pm 16.5 \mathrm{~g} / \mathrm{d}$, and $54.9 \pm 16.5 \mathrm{~g} / \mathrm{d}$, respectively. In the oldestold group, energy, carbohydrate, protein, and fat intake were found to be $1,111.8 \pm 198.7 \mathrm{kcal} / \mathrm{d}, 119.5 \pm 27.9 \mathrm{~g} / \mathrm{d}, 41.5 \pm 11.0$ $\mathrm{g} / \mathrm{d}$, and $48.5 \pm 7.7 \mathrm{~g} / \mathrm{d}$, respectively. In the oldest-old group, energy, carbohydrate, protein, and fat intake were found to be $1,111.8 \pm 198.7 \mathrm{kcal} / \mathrm{d}, 119.5 \pm 27.9 \mathrm{~g} / \mathrm{d}, 41.5 \pm 11.0 \mathrm{~g} / \mathrm{d}$, and $48.5 \pm 7.7 \mathrm{~g} / \mathrm{d}$, respectively. In all elderly at risk of poor nutritional status, energy, carbohydrate, protein, and fat intake were found to be $1,589.2 \pm 423.0 \mathrm{kcal} / \mathrm{d}, 203.5 \pm 66.9 \mathrm{~g} / \mathrm{d}, 56.9 \pm 17.1 \mathrm{~g} / \mathrm{d}$, and $55.6 \pm 21.0 \mathrm{~g} / \mathrm{d}$, respectively. In the young-old versus oldold, young-old versus oldest-old, and old-old versus oldest-old comparison energy and macronutrients intake were significantly different $(\mathrm{p}<0.001)$ (Table 5).
The level (\%) of meeting daily requirements for energy and nutrients intake according to RDA for the elderly at risk of poor nutritional status are given in Table 6 . The young-old elderly, who had the risk of poor nutritional status, met the requirements of vitamin $\mathrm{A}$, vitamin $\mathrm{E}$, vitamin B1, vitamin B2, vitamin B6, folate, vitamin C, sodium, calcium, magnesium, iron, copper, except for vitamin $\mathrm{B} 12$ and zinc. The old-old elderly met the requirements of daily intake of vitamin A, vitamin E, vitamin B1, vitamin B2, vitamin $\mathrm{B} 6$, folate, vitamin $\mathrm{C}$, sodium, magnesium, iron, copper, and did not meet the requirements for vitamin B12, calcium, and zinc. The oldest-old elderly met the requirements of most of the micronutrients except for vitamin B12, calcium, magnesium, iron, and zinc. There was the lowest intake of zinc and the highest intake of sodium. None of the groups met the B12 and zinc requirements. 
Table 6. Level of meeting daily requirements (\%) for energy and nutrient intake ( $N=140)$

\begin{tabular}{|c|c|c|c|c|}
\hline & $\begin{array}{c}\text { Young-old }(n=104) \\
\text { Mean (SD) }\end{array}$ & $\begin{array}{l}\text { Old-old }(n=23) \\
\text { Mean (SD) }\end{array}$ & $\begin{array}{l}\text { Oldest-old }(n=13) \\
\text { Mean (SD) }\end{array}$ & $\begin{array}{c}\text { Total } \\
\text { Mean (SD) }\end{array}$ \\
\hline Energy & $82.2(24.9)$ & $65.6(19.2)$ & $55.2(8.6)$ & $77.0(0.5)$ \\
\hline Carbohydrate & $68.2(0.9)$ & $58.1(17.0)$ & $50.4(10.1)$ & $67.6(20.9)$ \\
\hline Protein & $77.2(28.8)$ & $66.0(25.6)$ & $52.6(15.5)$ & $72.6(30.7)$ \\
\hline Lipid & $90.5(89.8)$ & $65.4(54.4)$ & $60.0(20.6)$ & $84.9(79.5)$ \\
\hline Vitamin A & $209.8(77.3)$ & $143.7(70.1)$ & $100.7(57.1)$ & $192.7(73.2)$ \\
\hline Vitamin E & $180.1(0.2)$ & $134.6(21.2)$ & $110.1(19.5)$ & $168.0(21.4)$ \\
\hline Vitamin B1 & $100.0(40.4)$ & 105.6 (41.1) & $106.5(42.1)$ & $98.2(39.6)$ \\
\hline Vitamin B2 & $97.6(25.1)$ & $76.1(31.7)$ & $75.5(35.6)$ & $92.8(88.4)$ \\
\hline Vitamin B6 & $111.5(42.7)$ & $101.6(41.8)$ & $87.8(30.0)$ & $106.1(103.4)$ \\
\hline Vitamin B12 & $58.5(29.0)$ & $50.6(24.3)$ & $40.6(27.3)$ & $55.1(55.1)$ \\
\hline Folate & $96.4(21.5)$ & $75.1(20.0)$ & $59.3(24.3)$ & $90.0(86.2)$ \\
\hline Vitamin C & 153.6 (48.3) & $144.4(30.5)$ & $135(29.3)$ & $146.4(45.5)$ \\
\hline Sodium & $250.6(100.1)$ & $299.0(131.1)$ & $376.4(44.0)$ & $258.0(91.5)$ \\
\hline Calcium & $67.1(12.1)$ & $60.5(10.7)$ & $49.1(6.8)$ & $62.6(11.3)$ \\
\hline Magnesium & $101.5(25.4)$ & $79.4(16.4)$ & $55.8(10.6)$ & $94.0(21.4)$ \\
\hline Iron & $76.4(15.3)$ & $72.1(17.4)$ & $42.7(10.3)$ & $70.8(14.4)$ \\
\hline Copper & $107.8(28.9)$ & $93.8(23.8)$ & $95.6(21.6)$ & $103.8(27.4)$ \\
\hline Zinc & $45.5(12.8)$ & $44.9(11.7)$ & $43.7(11.4)$ & $44.2(12.3)$ \\
\hline
\end{tabular}

\section{DISCUSSION}

\section{Nutritional Status}

Our study was based on MNA-SF. The malnutrition, malnutrition risk and normal nutrition ratios were found to be $8.6 \%, 42.1 \%$ and $49.1 \%$, respectively, whereas according to full MNA, they were $7.3 \%, 39.2 \%$ and $53.5 \%$, respectively.

A lot of studies have been carried out on appropriate BMI values for the elderly and close results were obtained. For instance, Soltoft et al. (19) stated that the elderly with BMI values between $25-27.5 \mathrm{~kg} / \mathrm{m}^{2}$ have the highest quality of life. Similarly, Garner et al. (20) stated that the highest quality of life was seen in females with BMI $24.5 \mathrm{~kg} / \mathrm{m}^{2}$ and in males with BMI $26 \mathrm{~kg} / \mathrm{m}^{2}$.

Ongan and Rakıcioglu (21) investigated 554 institutionalized elderly, whose mean age was $76.1 \pm 7.3$ years, mean BMI 26.5 was $9 \pm 4.58 \mathrm{~kg} / \mathrm{m}^{2}$ for males and $30.07 \pm 6.32 \mathrm{~kg} / \mathrm{m}^{2}$ for females. In our study mean age of the elderly was $70.1 \pm 5.1$ years, and mean BMI was $29.7 \pm 5.3 \mathrm{~kg} / \mathrm{m}^{2}$ for males and $30.0 \pm 3.4 \mathrm{~kg} / \mathrm{m}^{2}$ for females. In our study both free-living male and female elderly population had higher BMI value. The reason of this difference may be the place where they live. It is a remarkable finding that BMI value in the oldest-old group, which is $33.2 \pm 2.0 \mathrm{~kg} / \mathrm{m}^{2}$, is higher in comparison to younger-old groups $(\mathrm{p}<0.001)$. In fact, along with ageing, reasons such as the reduction in the basal metabolism rate, increase in the body fat percentage, and limitation of movement ability cause an increase in BMI (19). Also, there may not be enough area to move or limited access to physical therapy in the home environment.

In the international study performed by Kaiser et al. on different ethnical groups and nourishment habits, the BMI, WC and $\mathrm{W} / \mathrm{H}$ rates observed were close to each other (22). In our study, the oldest-old group had the highest BMI, the highest WC and the highest $\mathrm{W} / \mathrm{H}$ ratio. This situation gives rise to the thought of sarcopenic obesity, which is characterized by decreased muscle mass and increased fat mass. In old age, along with the reduction of the movement ability upon the decrease of the muscle mass, body fat mass increases and gaining weight again is realized by fat deposit especially in the abdominal region. This circumstance causes sarcopenic obesity (23). Therefore, only BMI is never enough for diagnosis of malnutrition.

The mean MUAC values in our study were $28.91 \pm 5.39 \mathrm{~cm}$, $30.86 \pm 3.91 \mathrm{~cm}$, and $21.24 \pm 1.38 \mathrm{~cm}$ for the young-old, old-old and oldest-old groups, respectively. MUAC is a measurement for the determination of the skeletal muscle protein mass and the indication of the nutrition status (24). In the study made by Charlton et al. (25) on 283 elderly individuals who were over 60 years of age, MUAC was $32.7 \pm 6.4 \mathrm{~cm}$. In our study, mean MUAC was $28.8 \pm 4.6 \mathrm{~cm}$ for males and $29.2 \pm 5.7 \mathrm{~cm}$ for females but according to age groups the lowest MUAC value was seen in the oldest-old group, the highest BMI, WC and $\mathrm{W} / \mathrm{H}$ ratio were seen at the same group as well. This fact suggests a serious muscle loss and malnutrition in the oldest-old free-living elderly.

In studies made on the free-living elderly using MNA, the malnutrition rate of $14.5 \%$ was found by Johansson et al. (26), and $14.7 \%$ by Pai (27). In the study performed by Simsek et al. in Turkey, the malnutrition and malnutrition risk rates were $2.7 \%$ and $28 \%$, respectively (28). In another study the malnutrition and malnutrition risk rates found by Sahin et al. were 5.8\% and 49.2\%, respectively (29). In our study, these rates were $7.2 \%$ and $39.2 \%$ according to MNA. This may be attributed to regional socioeconomic differences. Simsek et al. (28) performed their study in İzmir and Sahin et al. (29) performed the study in Kayseri. It is remarkable that in our province the malnutrition rate was slightly higher due to socioeconomic conditions (30). 


\section{Energy and Nutrients Intake}

Adequate energy and nutrient intakes are known to be important for maintaining nutritional status. Although in our study the young-old group and total of the elderly met the requirements of daily mean energy, carbohydrate, protein and lipids, the oldestold group only met the half of the macronutrient requirements. In comparisons of young-old versus old-old, young-old versus oldest-old, and old-old versus oldest-old, the energy and macronutrient intakes were significantly different $(\mathrm{p}<0.001)$. The young-old group did not meet the vitamin B12 and zinc requirements, the old-old group did not meet the vitamin B12, calcium and zinc requirements, and the oldest-old elderly can hardly meet any nutritional needs.

In all groups there was the lowest intake of zinc and the highest intake of sodium. None of the groups met the B12 and zinc requirements. The reasons for this may be indigestion or tooth loss, other diseases, or socioeconomic status.

An increased sodium intake and decreased calcium intake affects the bone health adversely (31). It is known that there is an increase in the consumption of sugar and salt by the elderly due to changes in taste perception (4).

Shahar et al. (32) investigation based on 24-hour nutrition intake inquiry in 377 free-living elderly found that $26 \%$ of the elderly did not meet the requirements according to RDA, and the oldest-old group received significantly less energy, fat and carbohydrate. Vitamin E, vitamin C and B1 intake was determined to be the lowest in this group as well.

In the study made on the institutionalized elderly, it was determined that all nutrient intakes of the elderly were favourable according to requirements except for calcium and magnesium (21). Similarly, in our study the most prevalent health problems were osteoporosis and hypertension, and the elderly get 2 times more sodium than recommended by RDA.

It is convenient that individuals for the purpose of their health stick to the Dietary Approaches to Stop Hypertension (DASH) diet, which is characterized by rich calcium, magnesium and poor sodium (33).

During the aging process, food consumption changes lead to less energy intake. This then appears as a reduction in muscle and bone masses. In addition, along with the reduction of physical activity, sarcopenic obesity may mask weight loss. Therefore, adequacy of food consumption is essential to slow down the process leading to malnutrition. Adequate and balanced nutrition will also reduce the need for future assisted-living facility admission by maintaining nutritional status and decreasing morbidity.

The present study has some limitations. First of all, this study was performed in one centre. Secondly, some chronic diseases and daily medicine use may affect the nutrition of the elderly. Finally, although various methods were applied to determine malnutrition, this study was performed with MNA-SF and MNA.

\section{CONCLUSIONS}

As the age progresses, malnutrition and inadequate nutrition intake progresses as well. In the free-living elderly, accompanied by some factors, may mask their weight loss. Elderly individuals, especially the free-living elderly, should decrease salt consumption and undergo regular geriatric control, which shall include not just the examination of their weight, but also a detailed control of their nutrients consumption by the health professionals.

\section{Conflict of Interests}

None declared

\section{REFERENCES}

1. Volkert D. Malnutrition in older adults - urgent need for action: a plea for improving the nutritional situation of older adults. Gerontology. 2013;59(4):328-33.

2. Yoshimura K, Yamada M, Kajiwara Y, Nishiguchi S, Aoyama T. Relationship between depression and risk of malnutrition among communitydwelling young-old and old-old elderly people. Aging Ment Health. 2013;17(4):456-60.

3. Li PF, Chen JS, Chang JB, Chang HW, Wu CZ, Chuang TJ, et al. Association of complete blood cell counts with metabolic syndrome in an elderly population. BMC geriatrics 2016; 16:1. doi: 10.1186/s12877-016-0182-9.

4. Yoshinaka M, Ikebe K, Uota M, Ogawa T, Okada T, Inomata C, et al. Age and sex differences in the taste sensitivity of young adult, young-old and old-old Japanese. Geriatr Gerontol Int. 2016.16(12):1281-8.

5. Sorokowska A, Schriever VA, Gudziol V, Hummel C, Hähner A, Iannilli $\mathrm{E}$, et al. Changes of olfactory abilities in relation to age: odor identification in more than 1400 people aged 4 to 80 years. Eur Arch Otorhinolaryngol. 2015;272(8):1937-44.

6. Ordonez AM, Madalozzo Schieferdecker ME, Cestonaro T, Cardoso Neto J, Ligocki Campos AC. Nutritional status influences the length of stay and clinical outcomes in patients hospitalized in internal medicine wards. Nutr Hosp. 2013;28(4):1313-20.

7. Guigoz Y, Vellas B, Garry PJ. Assessing the nutritional status of the elderly: The Mini Nutritional Assessment as part of the geriatric evaluation. Nutr Rev. 1996;54(1 Pt 2):S59-65.

8. Starr KNP, McDonald SR, Bales CW. Nutritional vulnerability in older adults: a continuum of concerns. Curr Nutr Rep. 2015;4(2):176-84.

9. DiMaria-Ghalili RA, Guenter PA. The mini nutritional assessment. Am J Nurs. 2008;108(2):50-9.

10. Guigoz Y, Lauque S, Vellas BJ. Identifying the elderly at risk for malnutrition. The Mini Nutritional Assessment. Clin Geriatr Med. 2002;18(4):73757.

11. Sarıkaya D, Halil M, Kuyumcu ME, Kilic MK, Yesil Y, Kara O, et al. Mini nutritional assessment test long and short form are valid screening tools in Turkish older adults. Arch Gerontol Geriatr. 2015;61(1):56-60.

12. Transgenerational Design Matters. The demographics of aging: characteristics of our aging population [Internet]. 2009 [cited 2018 Jun 1]. Available from: http://transgenerational.org/aging/demographics.htm.

13. Guigoz Y. The Mini Nutritional Assessment (MNA) review of the literature -- what does it tell us? J Nutr Health Aging. 2006;10(6):466-85; discussion 485-7.

14. Van Nes MC, Herrmann FR, Gold G, Michel JP, Rizzoli R. Does the mini nutritional assessment predict hospitalization outcomes in older people? Age Ageing. 2001;30(3):221-6.

15. Dietary Guidelines for Turkey. Recommended safe level of intake of energy and nutrients for Turkey [Internet]. Ankara: The Ministry of Health of Turkey, The General Directorate of Primary Health Care; 2006 [cited 2021 Jan 1]. Available from: http://www.bdb.hacettepe.edu. tr/dokumanlar/dietaryguidelines.pdf.

16. Rakıcıoglu N, Tek Acar N, Ayaz A, Pekcan G. Photograph catalog of food and dishes: portion sizes and amounts. 2nd ed. Ankara: Ata Ofset Publishing; 2009.

17. Merdol Kutluay T. Standard food rates for institutions. Ankara: Hatiboglu publishing house; 2003. (In Turkish.)

18. Jelliffe DB, Jelliffe EFP. Community nutritional assessment, assessment of ecological variables II. Food considerations. Oxford: Oxford Medical Publishing; 1989.

19. Soltoft F, Hammer M, Kragh N. The association of body mass index and health-related quality of life in the general population: data from the 2003 Health Survey of England. Qual Life Res. 2009;18(10):1293-9.

20. Garner R, Feeney DH, Thompson A, Bernier J, McFarland BH, Huguet $\mathrm{N}$, et al. Bodyweight, gender, and quality of life: a population-based longitudinal study. Qual Life Res 2012;21(5):813-25. 
21. Ongan D, Rakıcioglu N. Nutritional status and dietary intake of institutionalized elderly in Turkey: a cross-sectional, multi-center, country representative study. Arch Gerontol Geriatr. 2015;61(2):271-6.

22. Kaiser MJ, Bauer JM, Ramsch C, Uter W, Guigoz Y, Cederholm T, et al. Frequency of malnutrition in older adults: a multinational perspective using the mini nutritional assessment. J Am Geriatr Society. 2010;58(9):1734-8

23. Nair KS. Aging muscle. Am J Clin Nutr. 2005;81(5):953-63.

24. Lopez-Contreras MJ, Torralba C, Zamora S, Perez-Llamas F. Nutrition and prevalence of undernutrition assessed by different diagnostic criteria in nursing homes for elderly people. J Hum Nutr Diet. 2012;25(3):239-46.

25. Charlton KE, Kolbe-Alexander TL, Nel JH. The MNA, but not the DETERMINE, screening tool is a valid indicator of nutritional status in elderly Africans. Nutrition. 2007;23(7-8):533-42.

26. Johansson Y, Bachrach-Lindström M, Carstensen J, Ek AC. Malnutrition in a home-living older population: prevalence, incidence and risk factors. a prospective study. J Clin Nurs. 2009;18(9):1354-64.

27. Pai MK. Comparative study of nutritional status of elderly population living in the home for aged vs those living in the community. Biomed Res. 2011;22(1):120-6.

28. Simsek H, Meseri R, Sahin S, Ucku R. Prevalence of food insecurity and malnutrition, factors related to malnutrition in the elderly: a community-based, cross-sectional study from Turkey. Eur Geriatr Med. 2013;4(4):226-30.
29. Sahin H, Cicek B, Yilmaz M, Ongan D, Kaya N, Inanc N. Determining nutritional status and quality of life of 65 years and older individuals in Kayseri. Turk Geriatri Dergisi. 2013;16(3):322-9.

30. Acar S, Bilen Kazancik L, Meydan MC, Işik M. Socio-economic development ranking survey of provinces and regions: SEGE-2017 [Internet] Ankara: Ministry of Industry and Technology; 2019 [cited 2020 Jan 5]. Available from: https://www.bebka.org.tr/admin/datas/sayfas/89/ sege2017 1581687211.pdf. (In Turkish.)

31. Teucher B, Dainty JR, Spinks CA, Majsak-Newman G, Berry DJ, Hoogewerff JA, et al. Sodium and bone health: impact of moderately high and low salt intakes on calcium metabolism in postmenopausal women. J Bone Miner Res. 2008;23(9):1477-85.

32. Shahar D, Shai I, Vardi H, Fraser D. Dietary intake and eating patterns of elderly people in Israel: who is at nutritional risk? Eur J Clin Nutr. 2003;57(1):18-25.

33. Lin PH, Ginty F, Appel LJ, Aickin M, Bohannon A, Garnero P, et al. The DASH diet and sodium reduction improve markers of bone turnover and calcium metabolism in adults. J Nutr. 2003;133(10):3130-6.

Received August 22, 2019

Accepted in revised form January 6, 2021 